\title{
Indication of Holocene sea-level stability in the southern Laptev Sea recorded by beach ridges in north-east Siberia, Russia
}

\author{
Lasse Sander ${ }^{1}$, Rune Michaelis ${ }^{1}$, Svenja Papenmeier ${ }^{1,2}$, Sergey Pravkin ${ }^{3}$, Gesine Mollenhauer ${ }^{4}$, Hendrik \\ Grotheer $^{4}$, Torben Gentz ${ }^{4}$ \& Karen Helen Wiltshire ${ }^{1}$ \\ ${ }^{1}$ Alfred Wegener Institute, Helmholtz Centre for Polar and Marine Research, Wadden Sea Research Station, List/Sylt, Germany; \\ ${ }^{2}$ Leibniz Institute for Baltic Sea Research Warnemünde, Rostock, Germany; \\ ${ }^{3}$ Arctic and Antarctic Research Institute, St. Petersburg, Russia; \\ ${ }^{4}$ Alfred Wegener Institute, Helmholtz Centre for Polar and Marine Research, Marine Geochemistry, MICADAS Dating Laboratory, Bremerhaven, Germany
}

\begin{abstract}
The rapid warming of the Arctic may affect the stability of coastal geomorphological systems. Prograded sequences of wave-built deposits, so-called beachridge systems, preserve a proxy record of the long-term variability in the drivers of coastal evolution. Information on relative sea level (RSL), climate forcing and sediment supply can be reconstructed from these archives. Buor Khaya Bay is one of the few places along the Siberian Arctic coast where wide beachridge systems exist. A previously undescribed field site was surveyed in order to obtain information on the geomorphological processes along the modern shoreline under the current environmental conditions, and the characteristics of the Holocene beach-ridge deposits (e.g., elevation, sediment and age). Our data show that the system formed under storm wave/surge conditions. The beach ridges prograded ca. $1100 \mathrm{~m}$ between 6200 and 2600 cal yr BP, with only minor variations in surface elevation. This suggests a continuous and high sediment supply and similar storm wave run-up heights during that time. This relationship is interpreted as indicating RSL stability at a similar-to-present elevation during the period of beach-ridge formation. The hiatus in coastal progradation is concurrent with a deteriorating climate (cooling) in the Laptev Sea area and our data hence suggest increased rates of coastal change during periods of warmer climate conditions. Our study illustrates the potential of coastal sedimentary archives to provide a more complete view of the forcing, resilience and long-term evolution of unconsolidated Arctic coasts in a changing environment.
\end{abstract}

\section{Keywords}

Arctic coastal change; gravel beaches; coastal geomorphology; wave climate; Lena Delta; Buor Khaya Bay

\section{Correspondence}

Lasse Sander, Alfred Wegener Institute, Helmholtz Centre for Polar and Marine Research, Wadden Sea Research Station, Hafenstrasse 43, DE-25992 List/Sylt, Germany. E-mail: lasse.sander@awi.de

\author{
Abbreviations \\ cal yr BP: calibrated years before present \\ (defined as 1950); \\ GIS: geographical information system; \\ GPS: global positioning system; \\ Ky: thousands of years; \\ Kya: thousands of years ago; \\ Ky cal BP: thousands of calibrated years \\ before present (defined as 1950); \\ RSL: relative sea level
}

\section{Introduction}

Arctic coastal environments are currently undergoing rapid changes due to the Arctic amplification of the global climate warming trend, which affects the integrity and resilience of Arctic coastal systems (Jones et al. 2009; Overeem et al. 2011; Serreze \& Barry 2011; Günther et al. 2013; Irrgang et al. 2018). RSL, sediment supply and wave energy act as the controlling parameters, affecting shoreline stability and coastal evolution over the long-term (e.g., Goodwin et al. 2006; Allard et al. 2008; Billy et al. 2015; Fruergaard et al. 2015; Sander et al. 2016; Sander, Pejrup et al. 2018). A large proportion of the Siberian coast is composed of unconsolidated sediment and reacts sensitively to changes in external forcing (Rachold et al. 2000; Overduin et al. 2014; Sánchez-García et al. 2014). Many coastal areas of the Laptev Sea presently retreat at averaged rates between 0.1 and $5 \mathrm{~m} / \mathrm{yr}$ (Lantuit et al. 2012). Coastal erosion is linked to increased permafrost thaw, which results in the release of carbon and nutrients to the atmosphere and the marine environment (Wegner et al. 2015; Fritz et al. 2017). While coastal change is well documented over decadal timescales, the local trends and drivers of centennial- to millennial-scale coastal evolution are poorly understood for many of the remote areas of the world, including the Arctic shoreline of Siberia. Beach-ridge systems are wave-built coastal geomorphological features of global occurrence, with the potential 
to preserve information on the environmental conditions during their formation, such as RSL, wave climate, extreme storm surges, changes in sediment supply and sea-ice extent (e.g., Taylor \& Stone 1996; Otvos 2000; Brückner \& Schellmann 2003; Funder et al. 201 1; Scheffers et al. 2012; Tamura 2012; Sander et al. 2016; Nielsen et al. 2017).

Buor Khaya Bay (Sakha, Russian Federation) is an embayment about $100 \mathrm{~km}$ wide and $150 \mathrm{~km}$ long located in the shallow water $(<20 \mathrm{~m}$ deep) of the southern Laptev Sea, a marginal sea of the Arctic Ocean. Its eastern seaboard is dominated by the floodplain deposits of the Omoloy River and the retreating coastal yedoma bluffs of the Buor Khaya Peninsula (Fig. 1b; Günther et al. 2013; Strauss et al. 2013). While these soft-sediment shorelines react sensitively to changes in external forcing, the western seaboard of the embayment is defined by the relief of the Verkhoyansk Mountains, composed of sedimentary bedrock. A series of wavebuilt barriers, prograded spits and beach-ridge systems formed here within local topographic depressions (Sander, Michaelis et al. 2018).

The aims of this study were to (1) survey the geomorphology of local gravel- and pebble-dominated beaches under modern environmental conditions, (2) assess the surface characteristics and age of the prograded beach deposits and (3) reconstruct Holocene coastal evolution at the field site in order to infer past processes and changes in forcing parameters with a specific focus on Holocene RSL.

\section{Research area}

\section{Geology of Buor Khaya Bay}

The area of investigation is located in the south-western part of Buor Khaya Bay (Fig. 1). The geomorphology of the coastline is determined by the tectonic regime and structural geology of the Verkhoyansk Mountain range and the adjacent parts of the shallow Laptev Sea shelf (Drachev et al. 1998). The bedrock at the modern shore is composed of clastic sequences of Carboniferous to Triassic age (Trešnikov 1985; Parfenov 1991). Overall, the geological inheritance of the mountain range determines the lithology and antecedent topography (i.e., situation prior to the mid-Holocene marine transgression) at the field site.

\section{Modern climate and environmental conditions}

The modern climate of the area can be characterized as a dry, cold Subarctic and continental climate with a total annual precipitation of ca. $200 \mathrm{~mm}$ and a mean annual temperature of about $-15{ }^{\circ} \mathrm{C}$ (Shahgedanova 2002). The coast of southern Buor Khaya Bay is covered with fast sea ice between October and June, with interannual fluctuations of several weeks (Lantuit et al. 2011; Bogorodski et al. 2015). The amount and timing of the fluvial discharge from the Lena River strongly influence water temperature and salinity in the embayment during the open-water season. Surface salinities are on the order of 2-10\% during the summer months, with a halocline at water depths of around $5 \mathrm{~m}$ below the sea surface (Charkin et al. 2011). Lena River peak runoff occurs in June and the highest temperatures in Buor Khaya Bay are reached in July: nearly $16{ }^{\circ} \mathrm{C}$ (Yang et al. 2002; Lantuit et al. 2011). Large rivers, like the Lena, transfer huge amounts of heat from central Siberia to the Arctic Ocean, which affects the timing of the break-up of fast ice and, consequently, the length of the open-water season (Peterson et al. 2002). Buor Khaya Bay has a microtidal regime with an astronomical tidal range of $0.4 \mathrm{~m}$ (Pavlov et al. 1996; Fofonova et al. 2014). Because of the shape and orientation of Buor Khaya Bay, water levels are subject to pronounced episodic fluctuations under the influence of storms, producing surges with heights of $2.5 \mathrm{~m}$ or higher (Pavlov et al. 1996; Ashik \& Vanda 1995). Most storms occurring during the summer months have a western to south-western direction (ca. 54\%), while storm-force winds from the more significant eastern and north-eastern sectors occur 5-20 times per decade (ca. 14\%), as recorded in the period 1958-2006 (Lantuit et al. 2011).

\section{Holocene sea-level and climate history}

Very few adequate data sets are available on late Holocene RSL within the southern Laptev Sea (Baranskaya et al. 2018). The RSL development in north-east Siberia is primarily controlled by the global (eustatic) signal over Holocene timescales (Bauch, Müller-Lupp et al. 2001). The Laptev Sea is a shallow shelf sea and a far field site from the main Pleistocene ice sheets, and the role of glacial isostatic uplift and hydro-isostatic loading is therefore minor (Proshutinsky et al. 2004; Whitehouse et al. 2007; Klemann et al. 2015). Uplifted blocks of late Pleistocene deposits are found on Bykovsky Peninsula and at several locations in the Lena Delta, suggesting the occurrence of slow uplift movements since their time of formation (Are $\&$ Reimnitz 2000; Schwamborn 2004). Sea-level data for the East Siberian Sea suggest a rapid RSL rise on the order of 5-7 mm/yr between 10 and 6 Kya (Degtjarenko et al. 

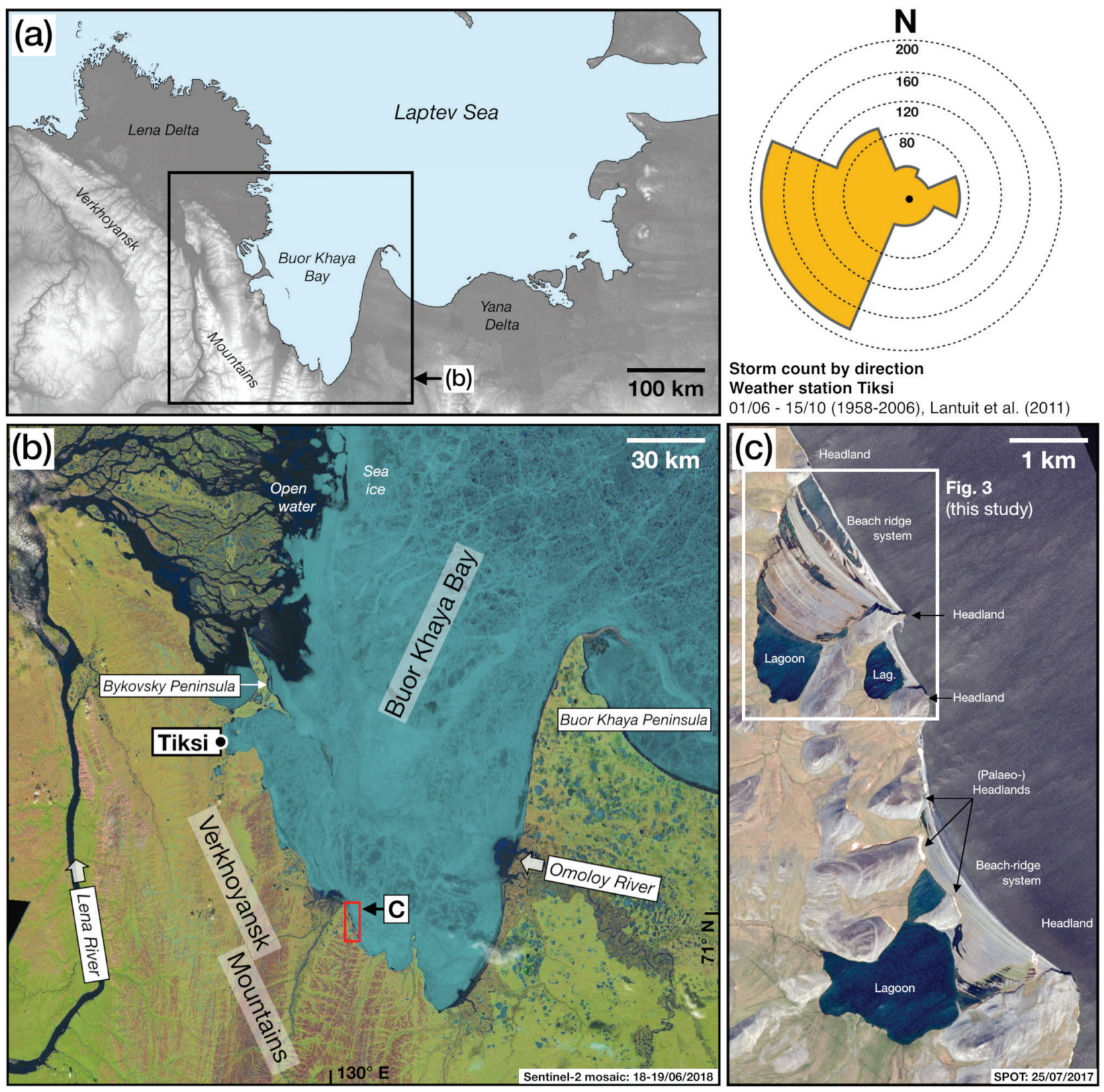

Fig. 1 Overview of the research area and the investigated field site. (a) Buor Khaya Bay is located south-east of the Lena Delta, between the Verkhoyansk mountains, the coastal lowlands of the Siberian Yedoma region and the southern Laptev Sea. (b) The bight remains covered by fast sea ice until late June. The western shoreline has a rugged shape and is dominated by bedrock, while its eastern counterpart is a soft-sediment dominated shoreline subject to coastal erosion (Günther et al. 2013). (c) The investigated beach-ridge system is located in a topographical low within the denudated mountain relief and formed between protruding headlands.

1982, cited by Pirazzoli 1991), a rate that is in broad agreement with the general trend of postglacial global sea-level rise (Fleming et al. 1998). The Laptev Sea shelf was transgressed during the early Holocene and the RSL may have reached an elevation similar to the present elevation at ca. 5 Kya and subsequently entered a period of relative stability (Bauch, Müller-Lupp et al. 2001). Based on marine signals in fluvial deposits of the Lena River Delta, Bolshiyanov et al. (2015) propose the occurrence of marked RSL fluctuations in the Laptev Sea 
over the mid- to Late Holocene, with highstands of $5 \mathrm{~m}$ and lowstands of 1-2 m above present mean sea level.

The past climate of north-east Siberia can be characterized by warmer conditions since the early Holocene that shifted to a cooler (modern) climate in the late Holocene. The timing of the transition is, however, not universally recognized in all reconstructions from the region (see Biskaborn et al. 2016 for a review). Andreev et al. (2004) infer the occurrence of an unstable, or cooling, climate as early as 5.8-3.7 Kya. By contrast, pollen records from the coastal regions of the southern Laptev Sea indicate the prevalence of a slightly warmer-than-present climate until 3.7-3.3 Kya (Andreev et al. 2011 and references therein). The time and extent of warmer climate in the mid-Holocene represent a crucial variable, influencing the length of the open-water season in Buor Khaya Bay, and thus the wave forcing of the study area.

\section{Beach-ridge systems}

Coarse clastic beaches occur along wave-dominated sedimentary shorelines with sufficient sediment supply and are essentially formed by storm wave run-up (e.g., Orford et al. 1991; St-Hilaire-Gravel et al. 2010). Beach-ridge systems are "progradational sedimentary systems [...] composed of a succession of shore-parallel ridges (the beach ridges) of more or less pronounced topography" (Goslin \& Clemmensen 2017: 83) and can be used to obtain indications of past sea level and other forcing parameters of coastal evolution over time (e.g., Brückner \& Schellmann 2003; Billy et al. 2015; Hede et al. 2015; Nielsen et al. 2017). The four principal controls on the geomorphology of gravel beach ridges are (1) sediment supply and source characteristics, (2) the rate and direction of sea-level change, (3) the topography and bathymetry at the study site and (4) the wave climate during beachridge formation (St-Hilaire-Gravel et al. 2010 and references therein). The topography of modern coarse-clastic beaches is usually composed of a steeply inclined beach face, where coarse material dominates, and a less inclined upper shoreface, often composed of sand; there is, however, a large variation of forms (Carter \& Orford 1993). The porosity of the beachface of coarse systems determines that percolation of the wave run-up attenuates the backwash, leading to a reduction in seaward transport and an increased deposition of wave-entrained clasts on the beachface. The result of this process is aggradation and the formation of a ridge around the swash limit (Orford et al. 1991; Tamura 2012). The elevation of coarse clastic, storm-built ridges is up to several meters above mean sea level and variability is primarily attributed to local differences in wave climate and storm exposure (Forbes et al. 1995; Otvos 2000; St-Hilaire-Gravel et al. 2010; Tamura
2012; Lindhorst \& Schutter 2014). Despite their susceptibility to variations in response to storm character, gravel ridges directly reflect wave processes and are therefore a relatively reliable indicator of sea level (Tamura 2012). However, regarding coarse clastic beach ridges, Orford et al. (1991) state that no simple and universal relationship exists between crest height and relative sea level; hence, slight variations in crest height across a beachridge system may not reflect sea-level changes.

\section{Methods}

\section{Remote sensing and other geospatial data}

Remotely sensed data were used for the preparation of the campaign and for the subsequent interpretation of the field data (Table 1). The data were synthesized in a GIS suite (QGIS, ESRI ArcGIS) in order to retrieve information on the general geographical context of the area. The interpretation was supported by information from the literature and by thematic maps. Only the Sentinel-2 and SPOT satellite imagery were used for the interpretation of the local geomorphological setting at the investigated site. The GIS observations were ground-truthed in the field and supported by kite aerial photography surveys (see Sander 2014 for a description of the kite set-up).

\section{GPS elevation measurements}

Fieldwork was conducted in August 2017 and August 2018. Elevation profiles were recorded using a Leica CS10/CS15 differential GPS with a base station recording stationary elevation data for at least two consecutive hours. The raw data were corrected to values relative to WGS84 using the AUSPOS Online GPS Processing Service (Geoscience Australia; ga.gov.au/bin/gps.pl). The estimated vertical uncertainty is approximately $\pm 10 \mathrm{~cm}$. Beach and beach-ridge profiles were oriented in a crossridge direction, perpendicular to the modern shoreline.

\section{Radiocarbon dating}

Age control was established by the radiocarbon dating of wood samples retrieved from driftwood buried in the beach deposits (MICADAS Laboratory, Alfred Wegener Institute, Helmholtz Centre for Polar and Marine Research, Bremerhaven). The wood deposits were only accessible at a few locations in open frost cracks (Fig. 2) and in areas of intensive cryoturbation. Each sample for dating was obtained from the outermost tree ring. The wood was subjected to chemical leaching and cleaning following the acid-base-acid procedure. Material was first submerged in $1 \mathrm{M} \mathrm{HCl}$ (for 30 minutes at $60{ }^{\circ} \mathrm{C}$ ) 
Table 1 Overview of data sets used in the study.

\begin{tabular}{|c|c|c|c|c|c|}
\hline Type & Name & Scene ID & $\begin{array}{l}\text { Date of } \\
\text { acquisition }\end{array}$ & Spatial resolution & Source \\
\hline$\overline{\mathrm{DEM}^{\mathrm{a}}}$ & Arctic DEM & Release 6, v2.0, Tile: $61 \_42$ & NA & $5 \mathrm{~m} \times 5 \mathrm{~m}$ & $\begin{array}{l}\text { Polar Geospatial Center } \\
\text { (pgc.umn.edu) }\end{array}$ \\
\hline $\mathrm{DEM}^{\mathrm{a}}$ & ASTER GDEM v2 & N70E130, N71E129, N71E130 & NA & $\begin{array}{l}1 \text { arc-second; } \\
\text { ca. } 30 \mathrm{~m} \times 10 \mathrm{~m}\end{array}$ & $\begin{array}{l}\text { USGS EarthExplorer } \\
\text { (earthexplorer.usgs.gov) }\end{array}$ \\
\hline $\mathrm{DBM}^{\mathrm{b}}$ & GEBCO & NA & NA & $\begin{array}{l}30 \text { arc-seconds; } \\
\text { ca. } 900 \mathrm{~m} \times 300 \mathrm{~m}\end{array}$ & $\begin{array}{l}\text { General Bathymetric Chart } \\
\text { of the Oceans (gebco.net) }\end{array}$ \\
\hline $\begin{array}{l}\text { Multispectral } \\
\text { satellite data }\end{array}$ & Sentinel 2 & $\begin{array}{l}\text { L1C_T52WED_A009639_20170427T033537 } \\
\text { L1C_T52WED_A010311_20170613T032736 } \\
\text { L1C_T52WED_A010354_20170616T033734 } \\
\text { L1C_T52WED_A010497_20170626T033533 } \\
\text { L1C_T52WED_A010697_20170710T031539 } \\
\text { L1C_T52WED_A011026_20170802T032744 } \\
\text { L1C_T52WED_A011212_20170815T033735 } \\
\text { L1C_T52WED_A011598_20170911T032740 } \\
\text { L1C_T52WED_A012170_20171021T032746 }\end{array}$ & $\begin{array}{l}27 / 042017 \\
13 / 06 / 2017 \\
16 / 06 / 2017 \\
26 / 06 / 2017 \\
10 / 07 / 2017 \\
02 / 08 / 2017 \\
15 / 08 / 2017 \\
11 / 09 / 2017 \\
21 / 10 / 2017\end{array}$ & $\begin{array}{l}10 \mathrm{~m} \times 10 \mathrm{~m} \\
10 \mathrm{~m} \times 10 \mathrm{~m} \\
10 \mathrm{~m} \times 10 \mathrm{~m} \\
10 \mathrm{~m} \times 10 \mathrm{~m} \\
10 \mathrm{~m} \times 10 \mathrm{~m} \\
10 \mathrm{~m} \times 10 \mathrm{~m} \\
10 \mathrm{~m} \times 10 \mathrm{~m} \\
10 \mathrm{~m} \times 10 \mathrm{~m} \\
10 \mathrm{~m} \times 10 \mathrm{~m}\end{array}$ & $\begin{array}{l}\text { USGSC EarthExplorer } \\
\text { (earthexplorer.usgs.gov) }\end{array}$ \\
\hline Satellite image & $\mathrm{KH}-9,1210-5$ & DZB1210-500155L009001 & $17 / 07 / 1975$ & $\begin{array}{l}\text { 20-30 feet; } \\
\text { ca. 6-9 m }\end{array}$ & $\begin{array}{l}\text { USGS EarthExplorer } \\
\text { (earthexplorer.usgs.gov) }\end{array}$ \\
\hline Satellite image & SPOT 7 & $\begin{array}{l}\text { DS_SPOT7_20170725 } 0326119 \text { FR1_FR1_ } \\
\text { SV1_SV1_E131N71_01303 }\end{array}$ & $25 / 07 / 2017$ & $2 m \times 2 m$ & $\begin{array}{l}\text { AIRBUS (intelligence- } \\
\text { airbusds.com) }\end{array}$ \\
\hline
\end{tabular}

aDigital elevation model. ${ }^{b}$ Digital bathymetric model. 'US Geological Survey.

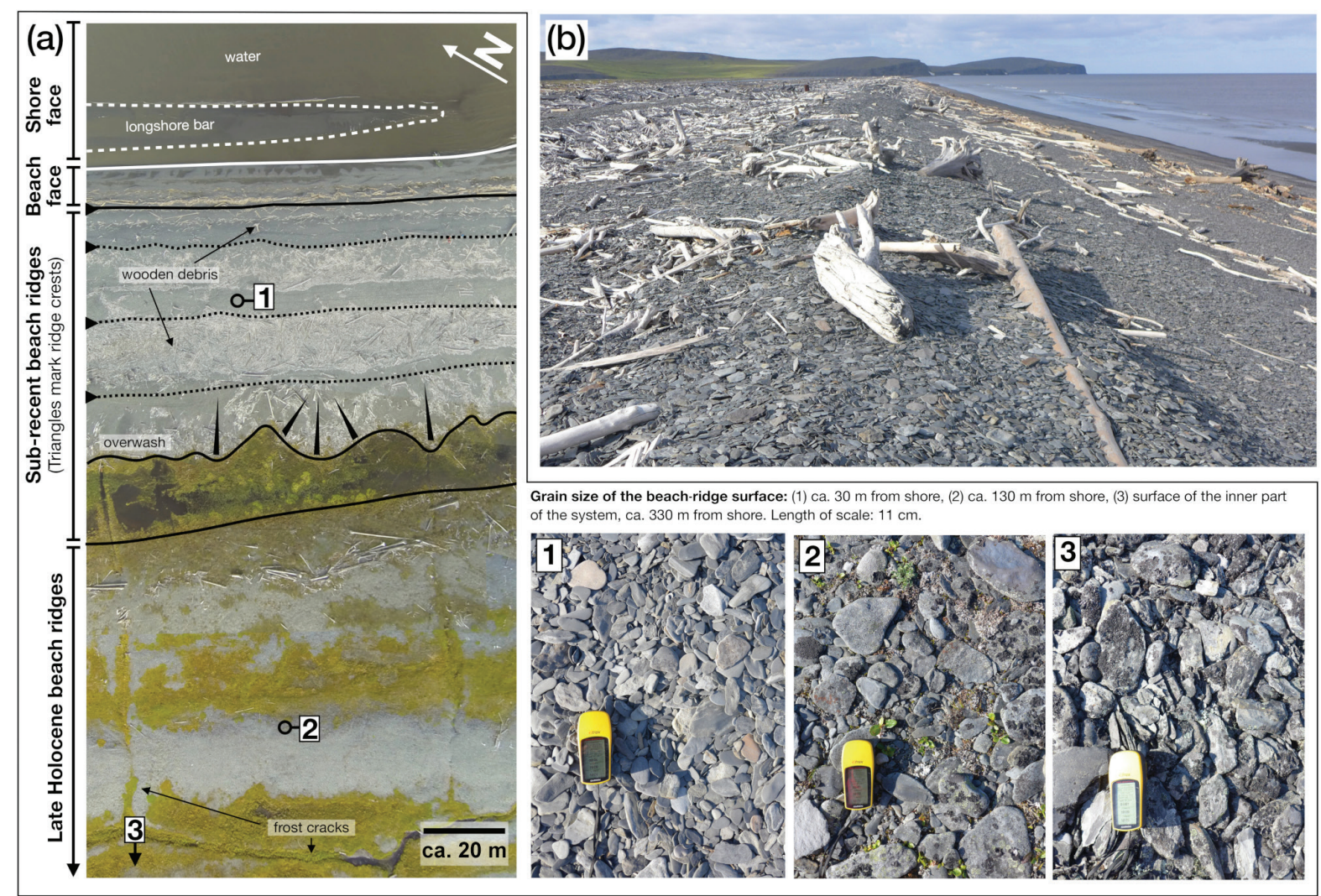

Fig. 2 (a) Surface properties of the outer part of the system with close-up images to illustrate the grain-size composition of clasts on the beach-ridge surface. (b) The modern storm berm has an elevation of 3 - $4 \mathrm{~m}$ above present mean sea level and is covered by ample amounts of wood debris. 
to remove carbonate contamination. Following rinsing with Milli-Q water, the samples were submerged in 1 $\mathrm{M} \mathrm{NaOH}$ (for 30 minutes at $60{ }^{\circ} \mathrm{C}$ ) to leach out humic acids. The base leaching was repeated until no colouring of the solution was evident, minimally seven times. Then the material was subjected to a final acid treatment ( $1 \mathrm{M} \mathrm{HCl} ; 30$ minutes at $60{ }^{\circ} \mathrm{C}$ ), rinsed to neutral with Mili-Q and dried for a minimum of 12 hours at $60{ }^{\circ} \mathrm{C}$. Milli-Q used for cleaning and acid/base solutions was pre-cleaned by liquid-liquid extraction with dichloromethane to remove remaining organic contamination. The samples were packed in tin capsules and combusted/ oxidized individually using an Elementar vario ISOTOPE EA (Elemental Analyzer) and produced $\mathrm{CO}_{2}$ was directly graphitized using the Ionplus AGE3 system (Automated Graphitization System; Wacker, Němec et al. 2010). The radiocarbon content of the samples was determined in reference to standards (oxalic acid II; National Institute of Standards and Technology reference code 4990c) and blanks (phthalic anhydride; Sigma-Aldrich 320064) using the Ionplus MICADAS dating system (Synal et al. 2007; Wacker, Bonani et al. 2010); blank correction and standard normalization was performed using the BATS software (Wacker, Christl et al. 2010). All the resulting ${ }^{14} \mathrm{C}$ ages were calibrated with the IntCall 3 calibration curve (Reimer et al. 2013) and an age model was constructed using OxCal 4.3 (Bronk Ramsey 2009).

\section{Results}

\section{Geomorphology and coastal evolution}

The field site is located within a reach of bedrockdominated shoreline and beach ridges formed at the entrance of a valley between two protruding headlands. The offshore waters are shallow $(<5 \mathrm{~m})$, a circumstance that influences the early formation and late decay of fast ice, as observed in the satellite data (Table 1). Active (currently exposed to wave energy) and inactive bedrock cliffs (shielded by beach deposits) are present at several locations around the field site and represent potential (past) sources of sediment. The gently inclined slopes of the Verkhoyansk Mountains in the hinterland of the field site are either barren or sparsely vegetated and are covered by a layer of cryoturbated debris. Valley floors are covered by a low herbaceous vegetation and show indication of slope-driven supra-permafrost drainage and the presence of an ice- and sediment-rich cover atop the bedrock (Grosse et al. 2007). A small lagoon is located in the innermost part of the valley and is entirely separated from the open water of Buor Khaya Bay by the beachridge system. Minor creeks, with small catchments, enter the lagoon at its south-western margin. Connected to the lagoon, small and shallow freshwater ponds form within low-lying areas of the beach deposits at both the northern and southern margins as well as in its central part. The beach deposits are divisible into at least one drowned ridge in the shallow waters of the lagoon, a succession of continuous swash-aligned beach ridges, an unconformity and two outer sets of recurved spits with an oblique orientation of beach ridges. Relatively continuous frost cracks are oriented roughly perpendicular to the orientation of the ridges and disintegrate towards the inner parts of the system, where more polygonal shapes occur. The outermost ridges are composed of thin barrier spits enclosing two shallow lagoons, dominated by marine conditions. The inner spit is breached by a small inlet, where both lagoons connect, and both spits reflect recurrent overwash deposition. The beach ridges have maximum elevations of $2.5-4.5 \mathrm{~m}$ (Fig. 3c) and are composed of pebble- to cobble-sized material (Fig. 2a). No aeolian deposits were observed.

The modern shoreline (Fig. 2) is composed of a low gradient upper shoreface with longshore intertidal bars composed of sands and gravels, and a steeply inclined beachface $\left(\right.$ ca. 6-9 $9^{\circ}$ with a storm berm elevation of 3-4 m composed of pebble- to cobble-sized material and significant amounts of wood debris. The steep angle of the modern beachface and the presence of overtopped debris indicate the prevalence of high-energy storm surges. The minerogenic beach deposits are composed of flat subangular to rounded clasts of low-grade metamorphic clay- or siltstone (Fig. 2a). The clasts are likely of local origin, given the high degree of similarity (colour and lithology) with the weathering products from adjacent bedrock cliffs.

\section{Age control}

A total of 13 samples were retrieved across the beachridge system to produce a chronology for the timing of its formation (Fig. 3a, Table 2). Samples K1-K4 were taken in 2017 and the ${ }^{14} \mathrm{C}$-ages of three different subsamples were determined from the innermost and the outermost preserved tree rings as well as from a transect through the entire sample. The age of the outermost ring of each sample was taken as most indicative for limiting the timing of the formation of the corresponding beach deposits containing the driftwood (i.e., the ridge is younger than the driftwood it contains). Nine additional samples were taken in 2018 in order to obtain a more solid chronology based on more evenly distributed samples. The ages are based on samples from the outermost preserved tree rings of stem disks, likewise obtained from driftwood contained within the beach-ridge deposits. The samples are ordered 

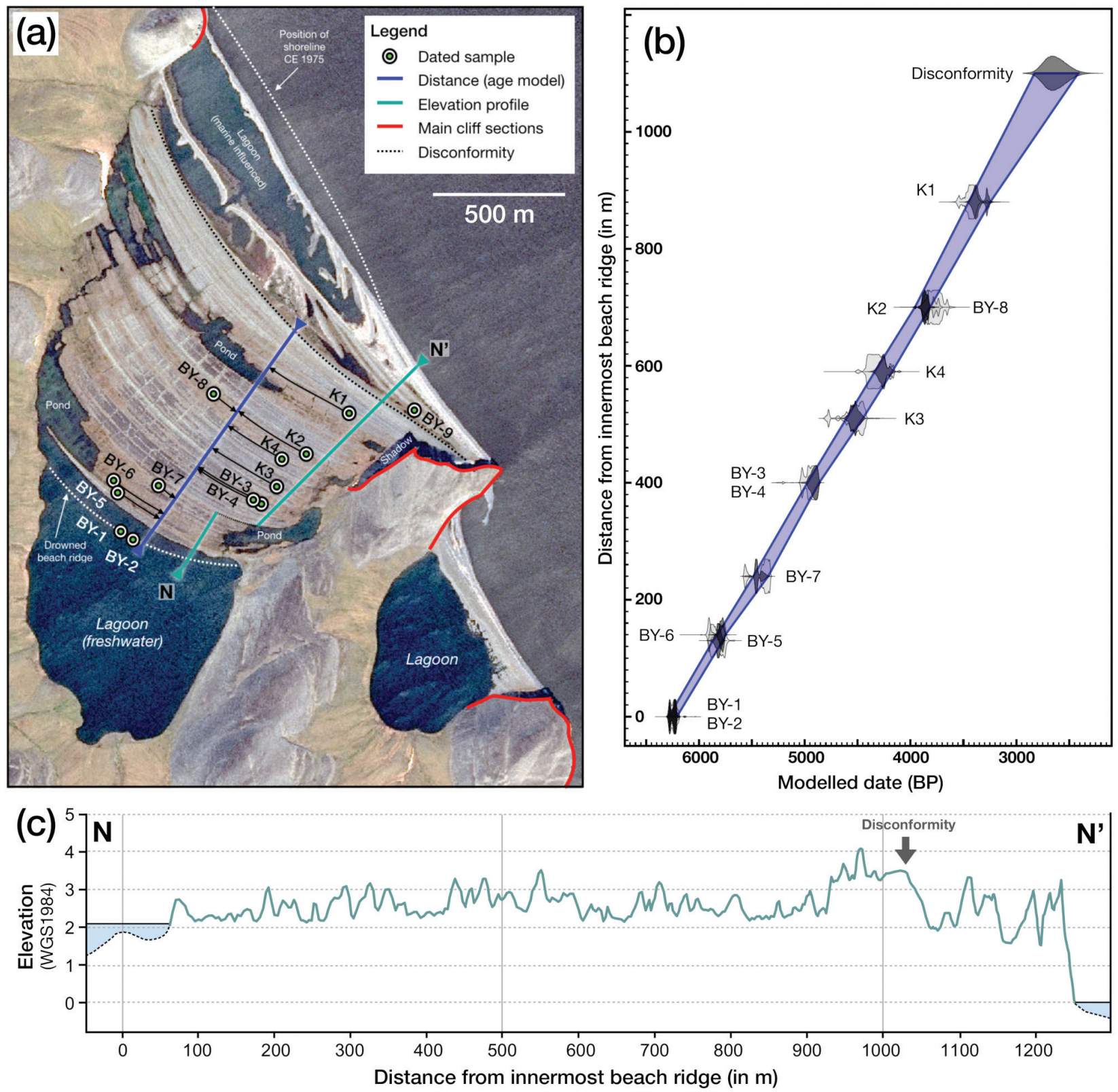

Fig. 3 (a) Satellite image of the investigated field site with the location of radiocarbon samples and the elevation transect. (b) Age model based on the radiocarbon samples. (c) GPS elevation transect.

by their distance from the innermost, and therefore conceptually oldest preserved, beach ridge.

Two samples from the innermost (drowned) beach ridge reveal a highly similar age for both samples suggesting an initiation of beach-ridge formation 6290-6205 cal yr BP (BY-1 and BY-2; Table 2). The first samples on the subaerial portion of the beach-ridge system likewise are very similar and reveal ages of 5870-5770 cal yr BP (BY-6) and 5825-5750 cal yr BP (BY-5). The consecutive samples along the profile have ages of 4970-4865 (BY-3 and BY-4), 4605-4450 (K3), 4340-4170 (K4), 3960-3815 (BY-8) and 3960-3815 cal yr BP (K2). The most seaward sample along the prograded part of the system dated between 3450 and 3245 cal yr BP (K1). The radiocarbon sequence lacks age inversions and the age model shows a linear trend with an averaged progradation rate of ca. $0.3 \mathrm{~m} / \mathrm{yr}$ between 6.2 and $3.3 \mathrm{cal}$ yr BP (Fig. 3b). After the initial beach ridges formed and prior to the hiatus 
Table 2 Overview of radiocarbon dates.

\begin{tabular}{|c|c|c|c|c|c|c|}
\hline Sample & Sample coordinate & Distance (m) & Laboratory code & ${ }^{14} \mathrm{C}$ age & Calibrated range $(2 \sigma)^{\mathrm{a}}$ & Modelled range $(2 \sigma)^{\mathrm{a}}$ \\
\hline$\overline{B Y}-1$ & $71^{\circ} 1.490^{\prime} \mathrm{N} / 130^{\circ} 10.402^{\prime} \mathrm{E}$ & 0 & 2292.1 .1 & $5425 \pm 30$ & $6290-6185$ & $6290-6205$ \\
\hline BY-2 & $71^{\circ} 1.482^{\prime} \mathrm{N} / 130^{\circ} 10.426^{\prime} \mathrm{E}$ & 0 & 2293.1 .1 & $5441 \pm 30$ & $6295-6195$ & $6290-6205$ \\
\hline BY-6 & $71^{\circ} 1.601^{\prime} \mathrm{N} / 130^{\circ} 10.326^{\prime} \mathrm{E}$ & 130 & 2297.1.1 & $5063 \pm 29$ & $5905-5740$ & $5870-5770$ \\
\hline BY-5 & $71^{\circ} 1.595^{\prime} \mathrm{N} / 130^{\circ} 10.329^{\prime} \mathrm{E}$ & 140 & 2296.1 .1 & $5118 \pm 29$ & $5930-5750$ & $5825-5750$ \\
\hline BY-7 & $71^{\circ} 1.616^{\prime} \mathrm{N} / 130^{\circ} 10.525^{\prime} \mathrm{E}$ & 240 & 2298.1 .1 & $4697 \pm 29$ & $5580-5320$ & $5490-5345$ \\
\hline BY-4 & $71^{\circ} 1.559^{\prime} \mathrm{N} / 130^{\circ} 11.309^{\prime} \mathrm{E}$ & 400 & 2295.1 .1 & $4380 \pm 29$ & $5040-4860$ & $4970-4865$ \\
\hline $\mathrm{K} 3$ & $71^{\circ} 1.593^{\prime} \mathrm{N} / 130^{\circ} 11.402^{\prime} \mathrm{E}$ & 510 & 1290.2 .2 & $4038 \pm 49$ & $4805-4415$ & $4605-4450$ \\
\hline K4 & $71^{\circ} 1.643^{\prime} \mathrm{N} / 130^{\circ} 11.466^{\prime} \mathrm{E}$ & 590 & 1291.2 .2 & $3889 \pm 49$ & $4430-4150$ & $4340-4170$ \\
\hline BY-8 & $71^{\circ} 1.810^{\prime} \mathrm{N} / 130^{\circ} 11.015^{\prime} \mathrm{E}$ & 700 & 2299.1 .1 & $3544 \pm 28$ & $3905-3720$ & $3960-3815$ \\
\hline K2 & $71^{\circ} 1.670^{\prime} \mathrm{N} / 130^{\circ} 11.656^{\prime} \mathrm{E}$ & 700 & 1289.2 .2 & $3500 \pm 48$ & $3895-3640$ & $3960-3815^{b}$ \\
\hline K1 & $71^{\circ} 1.728^{\prime} \mathrm{N} / 130^{\circ} 11.991^{\prime} \mathrm{E}$ & 880 & 1288.2 .2 & $3206 \pm 48$ & $3565-3350$ & $3450-3245$ \\
\hline Disconformity & (Fig. 3) & 1100 & NA & NA & NA & $2830-2415$ \\
\hline BY-9 & $71^{\circ} 1.798^{\prime} \mathrm{N} / 130^{\circ} 12.332^{\prime} \mathrm{E}$ & NA & 2300.1 .1 & $1145 \pm 29$ & $1145-975$ & NA \\
\hline
\end{tabular}

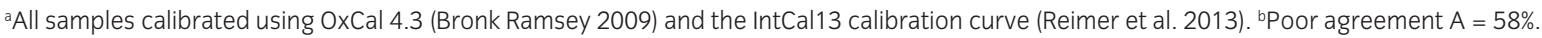

in progradation (disconformity), there is no indication, either in the chronology or in the spatial arrangement of the ridges, that suggests something other than the continuous, uninterrupted progradation of the system. Based on the age model, it can be said that the disconformity formed only after $2.6 \mathrm{cal}$ yr BP (Fig. 3b). A sample from the outer part of the system provides an age of 1145-975 cal yr BP (Table 2).

\section{Discussion}

Based on the remotely sensed data, the elevation information and the obtained age control, the studied beachridge system can be divided into four distinct parts: (1) a drowned initial and swash-aligned beach ridge that formed ca. 6.2 Ky cal BP, (2) a succession of prograded beach ridges with elevations between 3 and $4 \mathrm{~m}$ that formed between at least 5.8-2.6 Ky cal BP under conditions of high sediment and storm energy supply, (3) a disconformity evidencing a period of reduced sedimentation or preservation after ca. $2.6 \mathrm{cal}$ yr BP and (4) several recent phases of progradation with a more discontinuous pattern of ridge construction over late Holocene timescales (from ca. $1 \mathrm{Ky} \mathrm{cal} \mathrm{BP}$ ). The different parts of the system are discussed in the following paragraphs:

(1) The spatial arrangement of the initial beach ridge suggests a marine formation forced by waves refracted into the valley. The ridge is at its southern end connected to a hinge point in the shape of the shoreline and sediment likely originated from the preserved palaeocliffs at the southern margin of the system. The initial ridge was formed ca. 6.2 Ky cal BP and is located at a depth of ca. $0.5 \mathrm{~m}$ below the water level of the lagoon (BY-1 and BY-2). The first dated ridges on the prograded and subaerial part of the system trace back to ca. 5.8 Ky cal BP (BY-5 and BY-6). The difference in age and elevation is interpreted as indication for the stabilization of the postglacial RSL rise. The new data predate existing records from the Laptev Sea by more than 1000 years (Bauch, Müller-Lupp et al. 2001).

(2) Between 5.8 and $2.6 \mathrm{Ky} \mathrm{cal} \mathrm{BP}$, a succession of continuously prograded beach ridges were emplaced at elevations of 3-4 m. The geomorphology of the highest berm ridge at the modern beach is clearly influenced by high-energy storm wave conditions, while the presence of a lower storm berm, swell-influenced fair-weather cusps and sand-rich upper shoreface deposits suggests a combination of variable water levels and wave states in maintaining the overall sediment budget of the field site. However, as the system progrades, only the storm-built ridges are preserved at the surface of the system. The measured topography (Fig. 3c) is therefore exclusively related to the maximum wave run-up height during infrequent storm events. Based on the assumption of a constant wave run-up height, it can be inferred that the RSL has been similar-to-present during the entire period between 5.8 and $2.6 \mathrm{Ky}$ cal BP. This presents a clear advancement in the quality of data pertaining to the past elevation of Holocene sea level for the Laptev Sea (Fig. 4; Baranskaya et al. 2018) and suggests the absence of major fluctuation in RSL as proposed by Bolshiyanov et al. (2015).

(3) The origin of the disconformity occurring after ca. 2.6 Ky cal BP may be the result of changes in wave climate. In cold climates, winds and storms only have an effect during the open-water season and the presence of sea ice effectively reduces fetch. Biskaborn et al. (2016) propose that a warmer climate prevailed between the mid-Holocene transgression of the Laptev Sea shelf and 


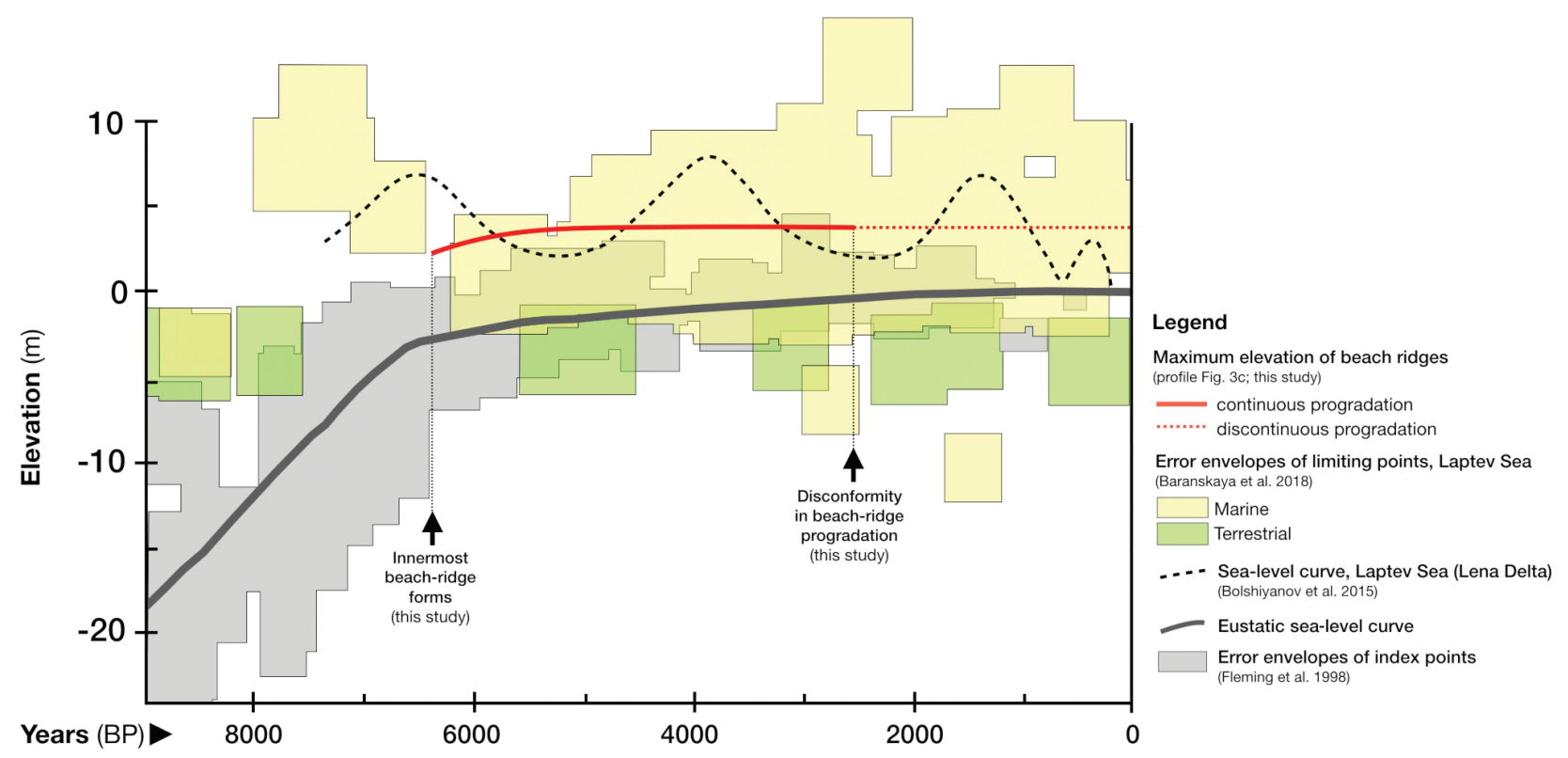

Fig. 4 Comparison of the new data (this study) with a compilation of existing sea-level information from previous investigations.

ca. 3.5 Kya. Bauch, Kassens et al. (2001: 349) document high sedimentation rates in a core from the Laptev Sea shelf, which they relate to "enhanced riverine runoff and/or erosion" between 7.6 and 4.0 Ky BP, which means increased supply of warmer water into the Laptev Sea (Bauch et al. 1999; Bauch, Kassens et al. 2001). In studies from the northern Lena Delta (Andreev et al. 2004) and from Bol'shoy Lyakhovsky Island (Andreev et al. 2007), Andreev and co-workers present evidence for unstable and slightly warmer-than-present climate conditions in the period 5.8-3.7 Kya. Records from the coastal regions of the Laptev Sea likewise indicate that a deterioration-a cooling - of the climate did not occur until around 3.7-3.3 Kya (Andreev et al. 2011). Studies from central Yakutia, further to the south, suggest that the warmer climate of the mid-Holocene persisted until ca. 2.5 Kya (Andreev et al. 2011 and references therein), which may have resulted in warmer riverine discharge into the Arctic. These data drawn from the literature suggest that warmer climate in the Laptev Sea may have predominated since the mid-Holocene marine transgression until some point between 4.0 and 2.5 Kya. We therefore infer the formation of continuously prograded parts of the system under climatic conditions, supporting a longer open-water season and hence an increased probability for the occurrence of storm events, delivering ample amounts of sediment to the studied field site.

(4) After ca. 2.6 Ky cal BP a series of spit systems formed that were repeatedly eroded partially and the sediment was moved alongshore towards the southern headland (Fig. 3). This change in the mode of progradation (from continuously built beach ridges to thin and mobile spits) was likely the result of changes in the amount and direction of sediment supply. A sample from the outer ridges yielded an age of $1.1 \mathrm{Ky}$ cal BP and may indicate the formation of a major set of ridges during the late Holocene, when warmer conditions may have lessened sea-ice cover and possibly influenced the delivery of wave energy and sediment to the study area. Because of the uneven progradation and the punctuated character of the outermost part of the beach-ridge record, this correlation remains a subject of further investigation. However, the elevation of the highest beach ridges in this outer set remains unchanged, suggesting that no considerable deviation in RSL occurred during the late Holocene.

\section{Conclusion}

Research on a coastal sedimentary system in Buor Khaya Bay has produced a record of sound indication on Holocene RSL for the southern Laptev Sea, as developed on the basis of the chronology and elevation of a prograded succession of beach ridges. The spatial arrangement of landforms suggests the establishment of a similar-to-present sea level between 6.2 and $5.8 \mathrm{Ky}$ cal BP and the continuation of ridge formation under stable RSL conditions until at least $2.6 \mathrm{Ky} \mathrm{cal} \mathrm{BP.} \mathrm{This} \mathrm{record} \mathrm{refines} \mathrm{the} \mathrm{timing} \mathrm{of} \mathrm{the}$ postglacial establishment of RSL stability in the area by more than 1000 years and provides substantial evidence for sea-level stability over mid-Holocene timescales. The 
data further suggest that the beach ridges formed during a warmer period with an increased open-water season and that the timing of a subsequent marked hiatus in progradation may point to the late termination of the warmer climate conditions in the Siberian Arctic. Overall, this study illustrates the potential of investigating onshore archives of coastal geomorphological change in the Siberian Arctic, with the aim of improving our current understanding of the principal forcing parameters of present coastal changes, and anticipating those acting in the future.

\section{Acknowledgements}

This study was conducted as part of the Russian-German Lena 2017 and 2018 expeditions, jointly coordinated by the Alfred Wegener Institute (Potsdam, Germany), the Arctic and Antarctic Research Institute (St. Petersburg, Russia) and the Melnikov Permafrost Institute (Yakutsk, Russia). We would like to express our gratitude for the indispensable logistical support of Waldemar Schneider and Volkmar Aßmann (both at the Alfred Wegener Institute, Potsdam). The crew of RV Nicole is thanked for facilitating access to the field site. Ivan Khristoforov and Kencheeri Danilov (both at the Melnikov Permafrost Institute, Yakutsk) are thanked for their participation and support during the second visit of the field site in 2018 . We would like to thank Owen Mason (University of Colorado) for providing constructive comments and language edits, which helped to improve the quality and focus of the manuscript. We further acknowledge the input provided by an anonymous reviewer.

\section{Funding}

This study was in-house funded by the Alfred Wegener Institute (Coastal Ecology).

\section{Disclosure statement}

The authors report no conflict of interest.

\section{References}

Allard J., Bertin X., Chaumillon E. \& Pouget F. 2008. Sand spit rhythmic development: a potential record of wave climate variations? Arçay Spit, western coast of France. Marine Geology 253, 107-131, doi: 10.1016/j.margeo.2008.05.009.

Andreev A., Grosse G., Schirrmeister L., Kuznetsova T.V., Kuzmina S.A., Bobrov A.A., Tarasov P.E., Novenko E.Y., Meyer H., Derevyagin A.Y., Kienast F., Bryantseva A. \& Kunitsky V.V. 2007. Weichselian and Holocene palaeoenvironmental history of the Bol'shoy Lyakhovsky Island, New Siberian Archipelago, Arctic Siberia. Boreas 38, 72-110, doi: 10.1111/j.1502-3885.2008.00039.x.

Andreev A., Schirrmeister L, Tarasov P.E., Ganopolski A., Brovkin V., Siegert C., Wetterich S. \& Hubberten H.-W. 2011. Vegetation and climate history in the Laptev Sea region (Arctic Siberia) during Late Quaternary inferred from pollen records. Quaternary Science Reviews 30, 2182-2199, doi: 10.1016/j.quascirev.2010.12.026.

Andreev A., Tarasov P., Schwamborn G., Ilyashuk B., Ilyashuk E., Bobrov A., Klimanov V., Rachold V. \& Hubberten H.-W. 2004. Holocene paleoenvironmental records from Nikolay Lake, Lena River Delta, Arctic Russia. Palaeogeography, Palaeoclimatology, Palaeoecology 209, 197-217, doi: 10.1016/j.palaeo.2004.02.010.

Are F. \& Reimnitz E. 2000. An overview of the Lena River Delta setting: geology, tectonics, geomorphology, and hydrology. Journal of Coastal Research 16, 1083-1093.

Ashik I.M. \& Vanda Y.A. 1995. Catastrophic storm surges in the southern part of the Laptev Sea. Berichte zur Polarforschung 176, 43-46.

Bauch H.A., Kassens H., Erlenkeuser H., Grootes P.M. \& Thiede J. 1999. Depositional environment of the Laptev Sea (Arctic Siberia) during the Holocene. Boreas 28, 194-204, doi: 10.1111/j.1502-3885.1999.tb00214.x.

Bauch H.A., Kassens H., Naidina O.D. Kunz-Pirrung M. \& Thiede J. 2001. Composition and flux of Holocene sediments on the eastern Laptev Sea Shelf, Arctic Siberia. Quaternary Research 55, 344-351, doi: 10.1006/ qres.2000.2223.

Baranskaya A.V., Khan N.S., Romanenko F.A., Roy K., Peltier W.R. \& Horton B.P. 2018. A postglacial relative sealevel database for the Russian Arctic coast. Quaternary Science Reviews 199, 188-205, doi: 10.1016/j.quascirev.2018.07.033.

Bauch H.A., Müller-Lupp T., Taldenkova E., Spielhagen R.F., Kassens H., Grootes P.M., Thiede J., Heinemeier J. \& Petryashov V.V. 2001. Chronology of the Holocene transgression at the North Siberian margin. Global and Planetary Change 31, 125-139, doi: 10.1016/ S0921-8181(01)00116-3.

Billy J., Robin N., Hein C.J., Certain R. \& FitzGerald D.M. 2015. Insight into the late Holocene sea-level changes in the NW Atlantic from a paraglacial beach-ridge plain south of Newfoundland. Geomorphology 248, 134-146, doi: 10.1016/j.geomorph.2015.07.033.

Biskaborn B.K., Subetto D.A., Savelieva L.A., Vakhrameeva P.S., Hansche A., Herzschuh U., Klemm J., Heinecke L., Pestryakova L.A., Meyer H., Kuhn G. \& Diekmann B. 2016. Late Quaternary vegetation and lake system dynamics in northeastern Siberia: implications for seasonal climate variability. Quaternary Science Reviews 147, 406-421, doi: 10.1016/j.quascirev.2015.08.014.

Bogorodski P.V., Makshtas A.P. \& Kustov V.Y. 2015. Rapid melting of fast-ice in the Buor-Khaya Bay. Polarforschung 85, 117-118, doi: 10.2312/polfor.2016.008

Bolshiyanov D., Makarov A. \& Savelieva L. 2015. Lena River delta formation during the Holocene. Biogeosciences 12, 579-593, doi: 10.5194/bg-12-579-2015. 
Bronk Ramsey C. 2009. Bayesian analysis of radiocarbon dates. Radiocarbon 51, 337-360, doi: 10.1017/S00338222 00033865.

Brückner H. \& Schellmann G. 2003. Late Pleistocene and Holocene shorelines of Andréeland, Spitsbergen (Svalbard): geomorphological evidence and palaeooceanographic significance. Journal of Coastal Research 19, 971-982.

Carter R.W.G. \& Orford J.D. 1993. The morphodynamics of coarse clastic beaches and barriers: a short-and longterm perspective. Journal of Coastal Research Special Issue 15, 158-179.

Charkin A.N., Dudarev O.V., Semiletov I.P., Kruhmalev A.V., Vonk J.E., Sánchez-García L., Karlsson E. \& Gustafsson Ö. 2011. Seasonal and interannual variability of sedimentation and organic matter distribution in the Buor-Khaya Gulf: the primary recipient of input from Lena River and coastal erosion in the southeast Laptev Sea. Biogeosciences 8, 2581-2594, doi: 10.5194/bg-8-2581-2011.

Degtjarenko Ju.P., Puminov A.P. \& Blagoveščenskij M.G. 1982. Beregovye linii vostočno-arktičeskih morej $\mathrm{V}$ pozdnem plejstocene i golocene. (Coastlines of east Arctic seas in the late Pleistocene and Holocene.) In P.A. Kaplin et al. (eds.): Kolebanija urovnja morej $i$ okeanov za 15000 let. (Sea and ocean level fluctuations over 15000 years.) Pp. 179-185. Moscow: Nauka.

Drachev S.S., Savostin L.A., Groshev V.G. \& Bruni I.E. 1998. Structure and geology of the continental shelf of the Laptev Sea, eastern Russian Arctic. Tectonophysics 298, 357-393, doi: 10.1016/S0040-1951(98)00159-0.

Fleming K., Johnston P., Zwartz D., Yokoyama Y., Lambeck K. \& Chappell J. 1998. Refining the eustatic sea-level curve since the Last Glacial Maximum using far- and intermediate-field sites. Earth and Planetary Science Letters 163, 327-342, doi: 10.1016/S0012-821X(98)00198-8.

Fofonova V., Androsov A., Danilov S., Janout M., Sofina E. \& Wiltshire K. 2014. Semidiurnal tides in the Laptev Sea Shelf zone in the summer season. Continental Shelf Research 73, 119-132, doi: 10.1016/j.csr.2013.11.010.

Fritz M., Vonk J.E. \& Lantuit H. 2017. Collapsing Arctic coastlines. Nature Climate Change 7, 6-7, doi: 10.1038/ nclimate 3188.

Fruergaard M., Møller I., Johannessen P.N., Nielsen L.H., Andersen T.J., Nielsen L., Sander L. \& Pejrup M. 2015. Stratigraphy, evolution, and controls of a Holocene transgressive-regressive barrier island under changing sea level: Danish North Sea coast. Journal of Sedimentary Research 85, 820-844, doi: 10.2110/jsr.2015.53.

Funder S., Goosse H., Jepsen H., Kaas E., Kjær K.H., Korsgaard N.J., Larsen N.K., Linderson H., Lyså A., Möller P., Olsen J. \& Willerslev E. 2011. A 10,000-year record of Arctic Ocean sea-ice variability-view from the beach. Science 333, 747-750, doi: 10.1126/science.1202760.

Goodwin I.D., Stables M.A. \& Olley J.M. 2006. Wave climate, sand budget and shoreline alignment evolution of the Iluka-Woody Bay sand barrier, northern New South Wales, Australia, since 3000 yr BP. Marine Geology 226, 127-144, doi: 10.1016/j.margeo.2005.09.013.
Goslin J. \& Clemmensen L.B. 2017. Proxy records of Holocene storm events in coastal barrier systems: stormwave induced markers. Quaternary Science Reviews 174, 80-119, doi: 10.1016/j.quascirev.2017.08.026.

Grosse G., Schirrmeister L., Siegert C., Kunitsky V.V., Slagoda E.A., Andreev A.A. \& Dereviagyn A.Y. 2007. Geological and geomorphological evolution of a sedimentary periglacial landscape in north-east Siberia during the Late Quaternary. Geomorphology 86, 25-51, doi: 10.1016/j. geomorph.2006.08.005.

Günther F., Overduin P.P., Sandakov A.V., Grosse G. \& Grigoriev M.N. 2013. Short- and long-term thermo-erosion of ice-rich permafrost coasts in the Laptev Sea region. Biogeosciences 10, 4297-4318, doi: 10.5194/bg-10-4297-2013.

Hede M.U., Sander L., Clemmensen L.B., Kroon A., Pejrup M. \& Nielsen L. 2015. Changes in Holocene relative sealevel and coastal morphology: a study of a raised beach ridge system on Samsø, southwest Scandinavia. The Holocene 25, 1402-1414, doi: 10.1177/0959683615585834.

Irrgang A.M., Lantuit H., Mason G.K., Günther F., Grosse G. \& Overduin P.P. 2018. Variability in rates of coastal change along the Yukon coast, 1951 to 2015. Journal of Geophysical Research-Earth Surface 123, 779-800, doi: 10.1002/2017JF004326.

Jones B.M., Arp C.D., Jorgenson M.T., Hinkel K.M., Schmutz J.A. \& Flint P.L. 2009. Increase in the rate and uniformity of coastline erosion in Arctic Alaska. Geophysical Research Letters 36, L03503, doi: 10.1029/2008GL036205.

Klemann V., Heim B., Bauch H.A., Wetterich S. \& Opel T. 2015. Sea-level evolution of the Laptev Sea and the East Siberian Sea since the last glacial maximum. Arktos 1, article no. 1, doi: 10.1007/s41063-015-0004-x.

Lantuit H., Atkinson D., Overduin P.P., Grigoriev M., Rachold V., Grosse G. \& Hubberten H.-W. 2011. Coastal erosion dynamics on the permafrost-dominated Bykovsky Peninsula, north Siberia, 1951-2006. Polar Research 30, article no. 7341, doi: 10.3402/polar.v30i0.7341.

Lantuit H., Overduin P.P., Couture N., Wetterich S., Aré F., Atkinson D., Brown J., Cherkashov G., Drozdov D., Forbes D.L., Graves-Gaylord A., Grigoriev M., Hubberten H.-W., Jordan J., Jorgenson T., Ødegård R.S., Ogorodov S., Pollard W.H., Rachold V., Sedenko S., Solomon S., Steenhuisen F., Streletskaya I. \& Vasiliev A. 2012. The Arctic Coastal Dynamics Database: a new classification scheme and statistics on Arctic permafrost coastlines. Estuaries and Coasts 35, 383-400, doi: 10.1007/s12237-010-9362-6.

Lindhorst S. \& Schutter I. 2014. Polar gravel beach-ridge systems: sedimentary architecture, genesis, and implications for climate reconstructions (South Shetland Islands/ Western Antarctic Peninsula). Geomorphology 221, 187-203, doi: 10.1016/j.geomorph.2014.06.013.

Nielsen L., Bendixen M., Kroon A., Hede M.U., Clemmensen L.B., Weßling R. \& Elberling B. 2017. Sea-level proxies in Holocene raised beach ridge deposits (Greenland) revealed by ground-penetrating radar. Scientific Reports 7, article no. 46460, doi: 10.1038/srep46460.

Orford J.D., Carter R.W. \& Jennings S.C. 1991. Coarse clastic barrier environments: evolution and implications for 
Quaternary sea level interpretation. Quaternary International 9, 87-104, doi: 10.1016/1040-6182(91)90068-Y.

Otvos E.G. 2000. Beach ridges-definitions and significance. Geomorphology 32, 83-108, doi: 10.1016/ S0169-555X(99)00075-6.

Overduin P.P., Strzelecki M.C., Grigoriev M.N., Couture N., Lantuit H., St-Hilaire-Gravel D., Günther F. \& Wetterich S. 2014. Coastal changes in the Arctic. London: Geological Society.

Overeem I., Anderson R.S., Wobus C.W., Clow G.D., Urban F.E. \& Matell N. 2011 . Sea ice loss enhances wave action at the Arctic coast. Geophysical Research Letters 38, L17503, doi: 10.1029/2011GL048681.

Parfenov L.M. 1991. Tectonics of the Verkhoyansk-Kolyma Mesozoides in the context of plate tectonics. Tectonophysics 199, 319-342, doi: 10.1016/0040-1951(91)90177-T.

Pavlov V.K., Timohov L.A., Baskakov G.A., Kulakov M.Y., Kurazhov V.K., Pavlov P.V., Pivovarov S.V. \& Stanovoy V.V. 1996. Hydrometeorological regime of the Kara, Laptev and East-Siberian seas. Technical Memorandum APL-UW TM 1-96. Seattle, WA: Applied Physics Laboratory, University of Washington.

Peterson B.J., Holmes R.M., McClelland J.W., Vörösmarty C.J., Lammers R.B., Shiklomanov A.I., Shiklomanov I.A. \& Rahmstorf S. 2002. Increasing river discharge to the Arctic Ocean. Science 298, 2171-2173, doi: 10.1126/ science. 1077445.

Pirazzoli P.A. 1991. World atlas of Holocene sea-level changes. Amsterdam: Elsevier.

Proshutinsky A., Ashik I.M., Dvorkin E.N., Häkkinen S., Krishfield R.A. \& Peltier W.R. 2004. Secular sea level change in the Russian sector of the Arctic Ocean. Journal of Geophysical Research-Oceans 109, C03042, doi: 10.1029/2003JC002007.

Rachold V., Grigoriev M.N., Are F.E., Solomon S., Reimnitz E., Kassens H. \& Antonow M. 2000. Coastal erosion vs riverine sediment discharge in the Arctic Shelf seas. International Journal of Earth Sciences 89, 450-460, doi: 10.1007/ s005310000113.

Reimer P.J., Bard E., Bayliss A., Beck J.W., Blackwell P.G., Ramsey C.B., Buck C.E., Cheng H., Edwards R.L., Friedrich M., Grootes P.M., Guilderson T.P., Haflidason H., Hajdas I., Hatté C., Heaton T.J., Hoffmann D.L., Hogg A.G., Hughen K.A., Kaiser K.F., Kromer B., Manning S.W., Niu M., Reimer R.W., Richards D.A., Scott E.M., Southon J.R., Staff R.A., Turney C.S.M. \& van der Plicht J. 2013. IntCall 3 and Marine 13 radiocarbon age calibration curves 0-50,000 years cal BP. Radiocarbon 55, 1869-1887, doi: 10.2458/azu_js_rc.55.16947.

Sánchez-García L., Vonk J.E., Charkin A.N., Kosmach D., Dudarev O.V., Semiletov I.P. \& Gustafsson Ö. 2014. Characterisation of three regimes of collapsing Arctic ice complex deposits on the SE Laptev Sea coast using biomarkers and dual carbon isotopes. Permafrost and Periglacial Processes 25, 172-183, doi: 10.1002/ppp.1815.

Sander L. 2014. Kite aerial photography (KAP) as a tool for field teaching. Journal of Geography in Higher Education 38, 425-430, doi: 10.1080/03098265.2014.919443.
Sander L., Hede M.U., Fruergaard M., Nielsen L., Clemmensen L.B., Kroon A., Johannessen P.N., Nielsen L.H. \& Pejrup M. 2016. Coastal lagoons and beach ridges as complementary sedimentary archives for the reconstruction of Holocene relative sea-level changes. Terra Nova 28, 43-49, doi: $10.1111 /$ ter. 12187.

Sander L., Michaelis R., Papenmeier S., Pravkin S. \& Wiltshire K.H. 2018. Characteristics of wave-built sedimentary archives in Buor Khaya Bay. Reports on Polar and Marine Research 725, 108-110.

Sander L., Pejrup M., Murray A.S., Perillo G.M., Raniolo L.A. \& Fruergaard M. 2018. Chronology and late-Holocene evolution of Caleta de los Loros, NE Patagonia, Argentina. The Holocene 28, 1276-1287, doi: 10.1177/0959683618771477.

Scheffers A., Engel M., Scheffers S., Squire P. \& Kelletat D. 2012. Beach ridge systems-archives for Holocene coastal events? Progress in Physical Geography 36, 5-37, doi: 10.1177/0309133311419549.

Schwamborn J.G. 2004. Late Quaternary sedimentation history of the Lena Delta. Reports on Polar and Marine Research 471. Bremerhaven: Alfred Wegener Institute.

Serreze M.C. \& Barry R.G. 201 1. Processes and impacts of Arctic amplification: a research synthesis. Global and Planetary Change 77, 85-96, doi: 10.1016/j.gloplacha.2011.03.004.

Shahgedanova M. 2002. Climate at present and in the historical past. New York: Oxford University Press.

St-Hilaire-Gravel D., Bell T.J. \& Forbes D.L. 2010. Raised gravel beaches as proxy indicators of past sea-ice and wave conditions, Lowther Island, Canadian Arctic Archipelago. Arctic 63, 213-226, doi: 10.14430/arctic976.

Strauss J., Schirrmeister L., Grosse G., Wetterich S., Ulrich M., Herzschuh U. \& Hubberten H.-W. 2013. The deep permafrost carbon pool of the Yedoma region in Siberia and Alaska. Geophysical Research Letters 40, 6165-6170, doi: 10.1002/2013GL058088.

Synal H.-A., Stocker M. \& Suter M. 2007. MICADAS: a new compact radiocarbon AMS system. Nuclear Instruments and Methods in Physics Research, Section B 259, 7-13, doi: 10.1016/j.nimb.2007.01.138.

Tamura T. 2012. Beach ridges and prograded beach deposits as palaeoenvironment records. Earth-Science Reviews 114, 279-297, doi: 10.1016/j.earscirev.2012.06.004.

Taylor M. \& Stone G.W. 1996. Beach-ridges: a review. Journal of Coastal Research 12, 612-621.

Trešnikov A.F. 1985. Atlas Arktiki. (Arctic atlas.) Moscow: General Directorate of Geodesy and Cartography.

Wacker L., Bonani G., Friedrich M., Hajdas I., Kromer B., Nemec M., Ruff M., Suter M., Synal H.-A. \& Vockenhuber C. 2010. MICADAS: routine and high-precision radiocarbon dating. Radiocarbon 52, 252-262, doi: 10.1017/ S0033822200045288.

Wacker L., Christl M. \& Synal H.A. 2010. Bats: a new tool for AMS data reduction. Nuclear Instruments and Methods in Physics Research, Section B 268, 976-979, doi: 10.1016/j. nimb.2009.10.078.

Wacker L., Němec M. \& Bourquin J. 2010. A revolutionary graphitisation system: fully automated, compact and simple. Nuclear Instruments and Methods in Physics 
Research, Section B 268, 931-934, doi: 10.1016/j.nimb. 2009.10.067.

Wegner C., Bennett K.E., de Vernal A., Forwick M., Fritz M., Heikkilä M., Łącka M., Lantuit H., Laska M., Moskalik M., O'Regan M., Pawłowska J., Promińska A., Rachold V., Vonk J.E. \& Werner K. 2015. Variability in transport of terrigenous material on the shelves and the deep Arctic Ocean during the Holocene. Polar Research 34, article no. 24964, doi: 10.3402/polar.v34.24964.
Whitehouse P.L., Allen M.B. \& Milne G.A. 2007. Glacial isostatic adjustment as a control on coastal processes: an example from the Siberian Arctic. Geology 35, 747-750, doi: 10.1130/G23437A.1.

Yang D., Kane D.L., Hinzman L., Zhang X., Zhang T. \& Ye H. 2002. Siberian Lena River hydrologic regime and recent change. Journal of Geophysical ResearchAtmospheres 107, article no. 4694, doi: 10.1029/2002JD 002542. 